\title{
THE ORIGIN OF POTTERY IN EAST ASIA AND ITS RELATIONSHIP TO ENVIRONMENTAL CHANGES IN THE LATE GLACIAL
}

\author{
Yaroslav V Kuzmin \\ Institute of Geology and Mineralogy, Siberian Branch of the Russian Academy of Sciences, Koptyug Ave. 3, Novosibirsk \\ 630090, Russia. Email: kuzmin@fulbrightmail.org.
}

\begin{abstract}
The chronometry of the origin of pottery in East Asia can give some insights to the question: did environmental changes trigger and/or accelerate innovations such as pottery-making, maritime adaptation, and agriculture? Recent results show that pottery emerged in 3 regions of East Asia: south China (up to $\sim 14,800 \mathrm{BP}$ ), the Japanese Islands (about 13,80013,500 BP), and the Russian Far East ( 13,300 BP). The earliest pottery in the Old World preceded the Bølling-Allerød warm period (about 13,000-11,500 BP). Thus, the relationship between climate and pottery origin was not "linear." It seems that the combination of environmental changes and the necessity to process freshwater fish and mollusks and terrestrial plants (including acorns and nuts) resulted in the introduction of pottery-making in East Asia. An important feature is the quite nonuniform nature of the Neolithization process in the eastern part of Asia, where often in 2 neighboring regions pottery appeared at very different times: approximately $15,000-14,000 \mathrm{BP}$ in south China and $\sim 4000 \mathrm{BP}$ in mainland Southeast Asia. Thus, the kind of eternal question like "What caused what?" still stands in terms of what were the driving forces for the emergence of pottery in East Asia and worldwide.
\end{abstract}

\section{INTRODUCTION}

The chronometry of the origin of pottery in East Asia can give us a clue to answer the eternal question in Old World archaeology: were environmental changes responsible for the emergence of innovations such as pottery-making, maritime adaptation, and agriculture? In order to get closer to the solution, one should compare the timing of the earliest pottery complexes with the general paleogeographic picture of a given region. In this overview, the data on the timing of the emergence of pottery (i.e. the beginning of the Neolithic in the "East Asian" sense of this term; see e.g. Kuzmin 2006, 2009) are considered against the general environmental background of East Asia and neighboring regions at the end of the Pleistocene, about 15,000-10,000 BP.

\section{MATERIAL}

For this review, the information available as of early 2010 was used. As for the definition of the term "pottery," I follow this one: "clay that has been fashioned into a desired shape and then dried to reduce its water content before being fired or baked to fix its form" (Darvill 2002:337-8). Previous data of the timeframe of pottery emergence in East Asia was summarized by Kuzmin (2006) and Kuzmin et al. (2009). In order to see a possible connection between the appearance of pottery and climatic fluctuations, the most complete records from Greenland ice cores (Rasmussen et al. 2006; Lowe et al. 2008) and Hulu Cave in China (Jiangsu Province) (Wang et al. 2001) are used as reference sources. According to them, the climate in south-central China during the Late Glacial was cold until $\sim 14,700$ cal BP and warmed up at about 14,700-13,000 cal BP; cold conditions (the Younger Dryas) occurred at about 13,000-11,600 cal BP (Wang et al. 2001). Pollen data from a long core in central China indicate relatively cold but mild climate at about 16,000-12,700 cal BP, and a cold spell (probably associated with the Younger Dryas) at about 12,700-11,000 BP (Zhu et al. 2010). Calibration of ${ }^{14} \mathrm{C}$ dates follows Reimer et al. (2004). This study employs a critical evaluation of ${ }^{14} \mathrm{C}$ records from the earliest Neolithic sites in East Asia called "chronometric hygiene" (see Kuz$\min 2006$ ).

(C) 2010 by the Arizona Board of Regents on behalf of the University of Arizona Proceedings of the 20th International Radiocarbon Conference, edited by A J T Jull RADIOCARBON, Vol 52, Nr 2-3, 2010, p 415-420 


\section{RESULTS AND DISCUSSION}

Kuzmin's (2006) model assumes that pottery in the Old World appeared for the first time in 3 distinct regions of East Asia: south China, the Japanese Islands, and the Russian Far East (Figure 1). In Japan, new data recently came to light from the northernmost island of Hokkaido. Here, the first appearance of pottery in Jomon (i.e. Neolithic; see e.g. Crawford 1996; Crawford and Takamiya 2008) complexes can be now stretched much further into antiquity. Considered for a long time as the backyard of the Japanese Jomon cultural sphere (i.e. Ikawa 1964:101-3; Morlan 1967a:199-202, 1967b; Kikuchi 1986), Hokkaido Island now has records compatible with the rest of the archipelago. The Taisho 3 site in southeastern Hokkaido revealed curved-based vessels. The "organic residue" attached to these vessels (charred food residue; T Yamahara, personal communication, 2009) was ${ }^{14} \mathrm{C}$ dated to about $12,470-12,120 \mathrm{BP}$ (in total, 11 values) (Yamahara 2006). The oldest pottery from Hokkaido is not much younger than that from main island of Honshu where the earliest Incipient Jomon complex at the Odai Yamamoto 1 site (Aomori Prefecture) is dated to $\sim 13,800-13,500$ BP (most probably, 13,500 BP; e.g. Keally et al. 2004). It should be noted that the age of the Incipient Jomon cultural component at the Odai Yamamoto 1 site is confirmed by the ${ }^{14} \mathrm{C}$ dates of the overlying Towada-Hachinohe tephra of 13,770-10,400 BP (Taniguchi 1999:136-7; see also Machida 1999:74; Nakamura et al. 2001:1134). Taniguchi and Kawaguchi (2001:488) give tephra ages of approximately $13,100-12,400 \mathrm{BP}$.

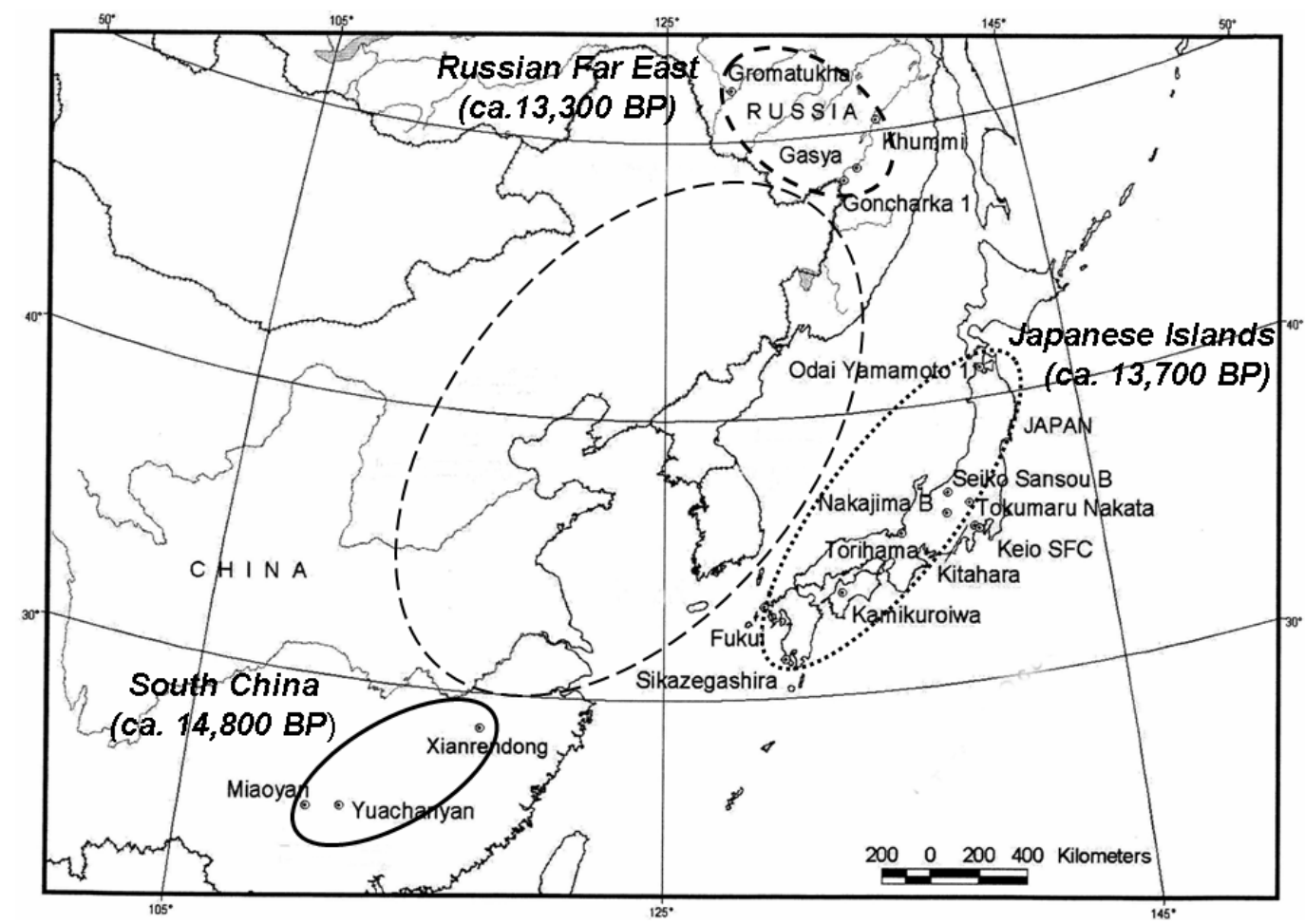

Figure 1 Major centers of the pottery origin in East Asia and its ages (after Kuzmin 2006, modified); thin-dashed oval shows the region with absence of pottery sites prior to $\sim 11,000 \mathrm{BP}$.

In far eastern Russia, the dates of the Initial Neolithic complexes of the Amur River basin, $\sim 13,300$ 12,300 BP (Kuzmin 2006:367), were additionally confirmed (Nesterov et al. 2006). Further west, in 
the conifer forest zone of the southern part of Eastern Siberia, new data testify in favor of the very early appearance of pottery, at least at about 11,200-10,800 BP and most probably up to $~ 12,200 \mathrm{BP}$ (Vetrov et al. 2006; Kuzmin and Vetrov 2007). This is significantly older than in the rest of Siberia (cf. Kuzmin and Orlova 2000; Weber at al. 2006). As for the Korean Peninsula, the strongest candidate for the earliest pottery is the Kosanni site on Cheju Island off the southern coast of mainland Korea (see Kuzmin 2006). In the absence of charcoal for ${ }^{14} \mathrm{C}$ dating, organic temper in flat-based pottery (Im 1999; Mylnikova and Nesterov 2008) was dated; however, the ${ }^{14} \mathrm{C}$ values are scattered from $\sim 10,200$ BP to $\sim 4500$ BP (Bae and Kim 2003).

In China, the situation has recently changed with new data obtained from the Yuchanyan site, located in Hunan Province, south of the Yangtze River. Previously, the pottery from this cave site was dated to $\sim 13,700 \mathrm{BP}$ (charcoal) and $\sim 14,400 \mathrm{BP}$ (organics in a potsherd) (Zhao and Wu 2000; see also Kuzmin 2006:364-5); the latter value is less reliable due to the uncertain relationship between the dated organic matter and the timing of ceramics manufacture (Kuzmin 2006:365). New excavations resulted in a series of ${ }^{14} \mathrm{C}$ dates closely associated with the earliest pottery, beginning at $\sim 14,800$ BP (Boaretto et al. 2009). Thus, Yuchanyan is today the place with the earliest pottery in East Asia and worldwide. This, however, does not radically alter Kuzmin's (2006) model because there is no evidence for diffusion of the pottery-making tradition from south China northwards (toward the Russian Far East) and eastwards (to the Japanese Islands), due to a lack of pottery sites between these regions prior to $\sim 11,000 \mathrm{BP}$ (Figure 1). It is still very probable that pottery was invented in several regions of East Asia independently at approximately the same time.

It is well known that the pace of the emergence of pottery worldwide was asynchronous, with East Asia as its "cradle." However, the advent of pottery was a slow process. The best available data we currently have come from Japan. Many sites belonging to the transitional period from the Upper Paleolithic to the Jomon have not yielded any pottery despite careful excavation of a comparatively large area; for example, at the well-studied Mikoshiba site in Nagano Prefecture (Hayashi 2008), no potsherds were found. There are no ${ }^{14} \mathrm{C}$ dates for this site, and the obsidian hydration date is $12,400 \pm 400 \mathrm{yr}$ (Hayashi 2008:330). Taniguchi (2006; see also Keally et al. 2003, 2004) stated that the quantity of potsherds in the earliest phase of the Incipient Jomon $(\sim 13,800-13,000 \mathrm{BP})$ was quite small, less than 100 at each site.

The increase in both the number of Jomon sites and the amount of potsherds began at about 12,800 11,500 BP (about 15,700-13,200 cal BP) (Taniguchi 2006); this corresponds in general to the Bølling-Allerød period. However, the real "explosion" in pottery production happened even later, at about 10,300-9000 BP, at the onset of the Holocene (Taniguchi 2006). The pollen records from Lake Suigetsu (Fukui Prefecture) in western Japan show an increase in pollen of broadleaved species (beech and oak) and Japanese cedar since 12,000 BP (Yasuda 2002:125). Progressive warming and expansion of broadleaved trees northward were typical for the Late Glacial period in central Japan, about 14,000-10,000 BP (Tsukada 1986:25-32). Taniguchi (2006) correlates the wide spread of Jomon sites with the flourishing of broadleaved species, oak and chestnut trees, and assumes that the earliest pottery was used for leaching and cooking acorns and chestnuts. Isotope data of the food crust on the earliest pottery at the Odai Yamamoto 1 site testify in favor of cooking terrestrial plants (Nakamura et al. 2001).

It is common that the appearance of some innovations (pottery and agriculture are among the best examples) in human society is connected to environmental changes driven by climatic fluctuations. Unfortunately, scholars often presume that there is a direct relationship between the emergence of innovations and climate with the prime role given to the environment. This is a kind of geographic 
determinism: “...environment (particularly its physical factors) dominates, even determines, the pattern of human life and human behavior, that people are largely conditioned by environmental factors." (Clark 2003:112). This belief is in fact a "dead end" because in most cases there is no direct correlation between the climate and the origin of pottery, agriculture, maritime adaptation, etc. Concerning the subject of this review, Taniguchi (2006; see also Taniguchi and Kawaguchi 2001; Keally et al. 2003:9-10) was the first who recognized that the beginning of pottery manufacture in Japan (about 17,200-14,200 cal BP) precedes the Bølling-Allerød warm period (about 14,700-12,900 cal BP) and coincides with the Oldest Dryas cooling (about 17,500-14,700 cal BP). Thus, pottery in Japan originated in "non-favorable" environmental conditions. The same is true for southern China where pottery is dated to $\sim 14,800 \mathrm{BP}(\sim 18,500 \mathrm{cal} \mathrm{BP})$ (Boaretto et al. 2009), when conifer forests dominated the environment in the central part of the Yangtze River basin (latitude around $30^{\circ} \mathrm{N}$ ) (e.g. Winkler and Wang 1993:233, 245). In general, the climate of central and southern China until $\sim 14,700$ cal BP (i.e. 12,500 BP) was cold (Wang et al. 2001:2346; see also Jiang and Piperno 1999; Zhao et al. 2003; Zhu et al. 2010).

Therefore, the beginnings of pottery-making and climatic changes in East Asia do not seem to have any direct relationship. The general trend was that gradual warming in the Late Glacial, since about 15,000-14,000 BP, and the expansion of broadleaved trees in Japan and south China somehow coincided with the emergence of pottery. However, in other parts of East Asia like the Amur River basin of the Russian Far East, pottery appeared at about 13,200-12,300 BP in an environment of conifer and birch-alder forests (Kuzmin 2003:21; Klimin et al. 2004). Further west, the Ust'-Karenga site in the southern part of Eastern Siberia with pottery dated to about 12,200-10,800 BP existed in a conifer forest biome (Vetrov et al. 2006; Kuzmin and Vetrov 2007). The use of lipid analysis for the study of the functions of prehistoric pottery (e.g. Craig et al. 2007) will definitely help to establish the purpose of the earliest pottery in East Asia and neighboring regions. It is clear that pottery originated in hunter-fisher-gatherer societies, and most probably the function of the earliest ceramics was utilitarian.

Another important line of evidence about the "non-linear" nature of the Neolithization process in East and Southeast Asia is the large difference between the first appearances of pottery in adjacent regions. For example, the earliest ceramics in south China are dated to $14,800 \mathrm{BP}$ (see above), but in northeast Thailand the first pottery was recently ${ }^{14} \mathrm{C}$ dated to about $3700-3400 \mathrm{BP}$ at the Ban Non Wat site (Higham and Higham 2009). In the absence of natural obstacles like high mountains, it seems unlikely that these 2 regions were isolated from each other in prehistory. Thus, the diffusion of pottery-making did not happen instantaneously, and in several places it appeared much later than in the "core" areas.

\section{CONCLUSION}

There is currently no answer to la question éternel in terms of the origin of pottery: "Which came first: the chicken or the egg?" (i.e. "What caused what?"). The most plausible explanation at the moment is that environmental conditions influenced the process of Neolithization, but the necessity to have containers for storage and processing food was also an important issue unrelated to the natural conditions. In the valleys of large rivers like the Amur in the Russian Far East, with an increase in fishing during the Initial Neolithic (about 13,000-12,000 BP) and the possible need of vessels for cooking and fat extraction from anadromous fish (different species of salmon) (see Medvedev 2008), the invention of pottery was probably determined by purely economic factors. A coupled analysis of the environmental, economic, and social components in the subsistence of prehistoric societies is necessary to find out what caused the emergence of pottery-making in particular regions. 


\section{ACKNOWLEDGMENTS}

This review arose from my long-term study of the Late Pleistocene and Holocene geoarchaeology of Northeast Asia, which began in 1979. Various aspects of research were supported since 1994 by different foundations and research/exchange programs, including the Russian Foundation for Basic Research (RFFI) (Russia); International Research and Exchange Board (IREX), Fulbright Program, and Civil Research and Development Foundation (CRDF) (USA); International Science Foundation (Soros Fund) and RFFI-CRDF program (Russia-USA); The Japan Foundation and Ministry of Education, Science, Culture and Sport (Mombu Kagakusho) (Japan); and Brain Korea 21 Fund and Korea Foundation (Republic of Korea). I am grateful to numerous colleagues from Russia, USA, Canada, UK, Slovenia, Japan, Korea, China, New Zealand, and Australia for support and fruitful discussions throughout the last 30 years. I also thank Prof T Nakamura (Nagoya University, Japan) for valuable comments on an earlier version of this article.

\section{REFERENCES}

Bae K, Kim JC. 2003. Radiocarbon chronology of the Palaeolithic complexes and the transition to the Neolithic in Korea. The Review of Archaeology 24(2): 46-9.

Boaretto E, Wu X, Yuan J, Bar-Yosef O, Chu V, Pan Y, Liu K, Cohen D, Jiao T, Li S, Gu H, Goldberg P, Weiner S. 2009. Radiocarbon dating of charcoal and bone collagen associated with early pottery at Yuchanyan Cave, Hunan Province, China. Proceedings of the National Academy of Sciences of the USA 106(24): 9595-600.

Clark AN. 2003. The Penguin Dictionary of Geography. 3rd edition. London: Penguin Books. 469 p.

Craig OE, Forster M, Andersen SH, Koch E, Crombé P, Milner NJ, Stern B, Bailey GN, Heron CP. 2007. Molecular and isotopic demonstration of the processing of aquatic products in northern European prehistoric pottery. Archaeometry 49(1):135-52.

Crawford G. 1996. Jomon tradition. In: Fagan BM, editor-in-chief. The Oxford Companion to Archaeology. Oxford: Oxford University Press. p 365-7.

Crawford GW, Takamiya H. 2008. Japanese Archipelago, prehistoric hunter-fisher-gatherers. In: Pearsall DM, editor-in-chief. Encyclopedia of Archaeology. Volume 1. Oxford: Academic Press. p 637-41.

Darvill T. 2002. The Concise Oxford Dictionary of Archaeology. Oxford: Oxford University Press. 506 p.

Hayashi S, editor. 2008. Mikoshiba Site: Excavation and Research at a Site Transitional from the Terminal Late Palaeolithic to the Incipient Jomon Period. Nagano: Shinmai Shoseki Publishing. In Japanese with English summary. $331 \mathrm{p}$.

Higham C, Higham T. 2009. A new chronological framework for prehistoric Southeast Asia, based on a Bayesian model from Ban Non Wat. Antiquity 83(319): $125-44$.

Ikawa F. 1964. The continuity of non-ceramic to ceramic cultures in Japan. Arctic Anthropology 2(2):95-119.

Im H-J. 1999. New discoveries in the Korean Neolithic archaeology. In: Omoto $\mathrm{K}$, editor. Interdisciplinary
Perspectives on the Origins of the Japanese. Kyoto: International Research Center for Japanese Studies. p 155-68.

Jiang Q, Piperno DR. 1999. Environmental and archaeological implications of a Late Quaternary palynological sequence, Poyang Lake, southern China. Quaternary Research 52(2):250-8.

Keally CT, Taniguchi Y, Kuzmin YV. 2003. Understanding the beginning of pottery technology in Japan and neighboring East Asia. The Review of Archaeology 24(2):3-14.

Keally CT, Taniguchi Y, Kuzmin YV, Shewkomud IY. 2004. Chronology of the beginning of pottery manufacture in East Asia. Radiocarbon 46(1):345-51.

Kikuchi T. 1986. Continental culture and Hokkaido. In: Pearson RJ, Barnes GL, Hutterer KL, editors. Windows on the Japanese Past: Studies in Archaeology and Prehistory. Ann Arbor: Center for Japanese Studies, University of Michigan. p 149-62.

Klimin MA, Kuzmin YV, Bazarova VB, Mokhova LM, Jull AJT. 2004. Late Glacial-Holocene environmental changes and its age in the Lower Amur River basin, Russian Far East: the Gursky peatbog case study. $\mathrm{Nu}$ clear Instruments and Methods in Physics Research B 223-224:676-80.

Kuzmin YV. 2003. The Paleolithic-to-Neolithic transition and the origin of pottery production in the Russian Far East: a geoarchaeological approach. Archaeology, Ethnology \& Anthropology of Eurasia 3(15):16-26.

Kuzmin YV. 2006. Chronology of the earliest pottery in East Asia: progress and pitfalls. Antiquity 80(308): 362-71.

Kuzmin YV. 2009. Radiocarbon and the Old World archaeology: shaping a chronological framework. $R a$ diocarbon 51(1):149-72.

Kuzmin YV, Jull AJT, Burr GS. 2009. Major patterns in the Neolithic chronology of East Asia: issues of the origin of pottery, agriculture, and civilization. Radiocarbon 51(3):891-903.

Kuzmin, YV, Orlova LA. 2000. The Neolithization of Si- 
beria and the Russian Far East: radiocarbon evidence. Antiquity 74(284):356-65.

Kuzmin YV, Vetrov VM. 2007. The earliest Neolithic complex in Siberia: the Ust-Karenga 12 site and its significance for the Neolithisation process in Eurasia. Documenta Praehistorica 34:9-20.

Lowe JJ, Rasmussen SO, Björck S, Hoek WZ, Steffensen JP, Walker MJC, Yu ZC, the INTIMATE group. 2008. Synchronisation of palaeoenvironmental events in the North Atlantic region during the Last Termination: a revised protocol recommended by the INTIMATE group. Quaternary Science Reviews 27(1-2):6-17.

Machida H. 1999. The stratigraphy, chronology and distribution of distal marker-tephras in and around Japan. Global and Planetary Change 21(1-3):71-94.

Medvedev VE. 2008. O nachalnom neolite Priamurya i keramike osipovskoi kultury [About the Initial Neolithic of the Amur River basin and the pottery of Osipovka culture]. In: Popov AN, editor. Neolit $i$ Neolitizatsiya Basseina Yaponskogo Morya: Chelovek i Istorichesky Landshaft. Vladivostok: Far Eastern State University Press. In Russian with English abstract. p 115-25.

Morlan RE. 1967a. The preceramic period of Hokkaido: an outline. Arctic Anthropology 4(1):164-220.

Morlan RE. 1967b. Chronometric dating in Japan. Arctic Anthropology 4(2):180-211.

Mylnikova LN, Nesterov SP. 2008. Fiziko-khimicheskoe issledovanie keramiki pamyatnika Kosanni: k probleme proiskhozhdeniya goncharsktva [Physicalchemical study of the Kosanni site pottery: to the problem of the origin of pottery-making]. In: Popov AN, editor. Neolit i Neolitizatsiya Basseina Yaponskogo Morya: Chelovek $i$ Istorichesky Landshaft. Vladivostok: Far Eastern State University Press. In Russian with English abstract. p 161-9.

Nakamura T, Taniguchi Y, Tsuji S, Oda H. 2001. Radiocarbon dating of charred residues on the earliest pottery in Japan. Radiocarbon 43(2B):1129-38.

Nesterov SP, Sakamoto M, Imamura M, Kuzmin YV. 2006. The Late-Glacial Neolithic complex of the Gromatukha site, Russian Far East: new results and interpretations. Current Research in the Pleistocene 23: 46-9.

Rasmussen SO, Andersen KK, Svensson AM, Steffensen JP, Vinther BM, Causen HB, Siggaard-Andersen M-L, Johnsen SJ, Larsen LB, Dahl-Jenses D, Bigler M, Röthlisberger R, Fischer H, Goto-Azuma K, Hansson ME, Ruth U. 2006. A new Greenland ice core chronology for the last glacial termination. Journal of Geophysical Research (Atmospheres) 111: D06102, doi: 10.1029/2005JD006079.

Reimer PJ, Baillie MGL, Bard E, Bayliss A, Beck JW, Bertrand CJH, Blackwell PG, Buck CE, Burr GS, Cutler KB, Damon PE, Edwards RL, Fairbanks RG, Friedrich M, Guilderson TP, Hogg AG, Hughen KA, Kromer B, McCormac G, Manning S, Bronk Ramsey C, Reimer RW, Remmele S, Southon JR, Stuiver M,
Talamo S, Taylor FW, van der Plicht J, Weyhenmeyer CE. 2004. IntCal04 terrestrial radiocarbon age calibration, 0-26 cal kyr BP. Radiocarbon 46(3):1029-58.

Taniguchi Y. 1999. Archaeological research at the Odai Yamamoto 1 site: summary. In: Odai Yamamoto 1 Site Excavation Team, editors. Archaeological Research at the Odai Yamamoto 1 Site: Inquiry into the Question of the End of the Palaeolithic Culture and the Beginning of the Jomon Culture. Tokyo: Kokugakuin University. p 135-44.

Taniguchi Y. 2006. Dating and function of the oldest pottery in Japan. Current Research in the Pleistocene 23: $33-5$.

Taniguchi Y, Kawaguchi J. 2001. ${ }^{14} \mathrm{C}$ ages and calibrated dates of the oldest pottery culture in the ChojakuboMikoshiba period. Daiyonki Kenkyu 40(6):485-98. In Japanese with English abstract.

Tsukada M. 1986. Vegetation in prehistoric Japan: the last 20,000 years. In: Pearson RJ, Barnes GL, Hutterer $\mathrm{KL}$, editors. Windows on the Japanese Past: Studies in Archaeology and Prehistory. Ann Arbor: Center for Japanese Studies, University of Michigan. p 11-56.

Vetrov VM, Kuzmin YV, Burr GS. 2006. The FinalPleistocene pottery of Siberia: Ust'-Karenga 12 site case study. Current Research in the Pleistocene 23: 49-51.

Wang YJ, Cheng H, Edwards RL, An ZS, Wu JY, Shen C-C, Dorale JA. 2001. A high-resolution absolutedated Late Pleistocene monsoon record from Hulu Cave, China. Science 294(5550):2345-8.

Weber AW, Beukens RP, Bazaliiskii VI, Goriunova OI, Savel'ev NA. 2006. Radiocarbon dates from Neolithic and Bronze Age hunter-gatherer cemeteries in the CisBaikal region of Siberia. Radiocarbon 48(1):127-66.

Winkler MG, Wang PK. 1993. The Late-Quaternary vegetation and climate of China. In: Wright HE Jr, Kutzbach JE, Webb T III, Ruddiman WF, Street-Perrott FA, Bartlein PJ, editors. Global Climates since the Last Glacial Maximum. Minneapolis: University of Minnesota Press. p 221-64.

Yamahara T. 2006. Taisho 3 site: the discovery of the earliest ceramic culture in Hokkaido. Current Research in the Pleistocene 23:35-6.

Yasuda Y. 2002. Origins of pottery and agriculture in East Asia. In: Yasuda Y, editor. The Origins of Pottery and Agriculture. New Delhi: Lustre Press \& Roli Books. p 119-42.

Zhao C, Wu X. 2000. The dating of Chinese early pottery and a discussion of some related problems. Documenta Praehistorica 27:233-9.

Zhao J-X, Wanf Y-J, Collerson KD, Gagan MK. 2003. Speleothem U-series dating of semi-synchronous climate oscillations during the last deglaciation. Earth and Planetary Science Letters 216(1-2):155-61.

Zhu C, Ma C, Yu S-Y, Tang L, Zhang W, Lu X. 2010. A detailed pollen record of vegetation and climate changes in Central China during the past 16000 years. Boreas 39(1):69-76. 